\title{
Erfaringer fra et familievernprosjekt
}

\author{
Ved Kirsti Foss
}

I de siste fire årene har det vaert drevet to selumordsforebyggende prosjekter i Molde, med Kirsti Foss som prosjektleder. Det første prosjektet var knyttet til sykehus, og dreide seg om oppretting av rutiner og kanaler for pasientbehandling og samarbeid rundt selumordsforsøkere. (Se noermere presentasjon i nr 3/98.) Dette var det naturlig å bygge videre på i det andre prosjektet som ble startet opp ved Familievernkontoret i Molde i januar 1996, i regi av Handlingsplan mot selvmord.

\section{Bakgrunn for prosjektet}

I "Bærumsmodellen", som vi er inspirert av, henviste man ofte selvmordsfors $\varnothing$ kere videre til det lokale familievernkontoret, og det ga positive resultater. Daglig leder på Familievernkontoret i Molde hadde lenge vært interessert i å legge forholdene til rette for et lokalt prosjekt hvor en kunne se på familievernets plass i det selvmordsforebyggende arbeidet. Dette falt sammen med Statens helsetilsyn sin målsetting om å starte opp modellfors $\varnothing \mathrm{k}$ $\mathrm{i}$ alle fylker.

\section{Hvordan tenkte vi?}

I november 1995 skrev Aftenposten om resultatene av den norske registreringen av selvmordsfors $\varnothing \mathrm{k}$ i regi av Verdens helseorganisasjon. Her sier professor Tore Bjerke om årsaksforhold når det gjelder selvmordshandlinger:

"Vanskelig familiesituasjon er den hyppigste årsak som oppgis blant dem som har forsøkt å ta livet sitt eller har påført seg selv alvorlige skader."

Dette utsagnet var både en bekreftelse på mine egne erfaringer fra møtet med selvmordsforsøkere og deres pårørende i prosjektet på Fylkessjukehuset i Molde, og det ble et argument for å satse på et prosjekt knyttet til familievernet. Her er vi opptatt av relasjoner, at mennesker hører sammen med andre mennesker. Ved selvmordshandlinger rammes mange rundt den selvmordsutsatte.

I prosjektet $\varnothing$ nsket vi å teste ut familievernets ståsted i det selvmordsforebyggende arbeidet. Overfor andre fagpersoner og instanser $\varnothing$ nsket vi å være pådrivere i forhold til et familieperspektiv.

\section{Hva fant vi?}

Vi vurderte Familievernkontoret sine klienter gjennom 2 år i forhold til selvmordsadferd. I det lille materialet fant vi at samlivsbrudd var årsak til selvmordsatferd/tanker hos 10 av 13 av de registrerte mennene.

Todelt familievernprosjekt

\section{Oppfølging av selvmordsforsøkere med par/} familieproblematikk

\section{2. Økt oppmerksomhet rundt temaet suicidalitet i par/familier}

\section{Ekstern informasjon:}

- info til berørte etater i aktuelle kommuner

\section{Eksternt samarbeid:}

- opprettet referansegruppe bestående av fagpersoner fra fylkeskommunalt og kommunalt nivå.

- planla en ny sykehusgruppe bestående av avdelingssykepleiere fra psykiatri og somatikk, ment som et viktig møtested for to behandlingskulturer hvor målet var et felles løft i forhold til selvmordsfors $\varnothing$ keren.

- laget en ny informasjonsbrosjyre for selvmordsfors $\varnothing$ kere og deres familier, som ble distribuert på sykehuset. Der beskrev vi kort på hvilken måte familievernet kunne være til hjelp.

\section{Prosjektleders rolle/erfaringer:}

- administrator over 2 år i 50 \% stilling

- erfarte godt faglig klima, viktig med regionalt og nasjonalt nettverk

For 7 av de 20 av de registrerte kvinnene var samlivsbrudd årsak til selvmordsatferd/tanker. Kvinner viser et mer sammensatt bilde. De tar også med psykiske/ somatiske/økonomiske problemer som forklaring på selvmordsadferd/tanker.

\section{Hvordan gikk det?}

Hvorfor fikk vi ikke til et bedre samarbeid med sykehuset rundt prosjektet på Familievernkontoret? Var det mangler ved organiseringen av prosjektet? Var det

\section{Undervisning/veiledning:}

- underviste lærere og elever i ungdomsog videregående skole i selvmordsforebygging/mestring av livskriser.

- veiledet berørte personer i skolen ved skoleelevers selvmordsfors $\varnothing \mathrm{k} /$ gjennomf $\varnothing$ rt selvmord.

- veiledet gruppeledere for en etterlattegruppe

- arrangerte seminarer/kurs for helseog sosialfaglig personell med fokus på familietilnærming ved selvmordsatferd.

\section{Egen kompetanseheving:}

- Utarbeidet et eget registreringsskjema for å studere eget klientgrunnlag. Hvordan lå det an med selvmordstanker og handlinger hos helt "vanlige" klienter på et familievernkontor?

\section{Henvisninger:}

Registrerte 33 personer (13 menn og 20 kvinner) over 2 år. Første prosjektår: 7 saker fra primærhelsetjenesten (etterlatte etter selvmord og annen selvmordsproblematikk i familier), 5 saker fra sykehuset (selvmordsfors $\varnothing$ kere). Andre prosjektår: ingen henvisninger

manglende lokal forankring? Eller var det forskjellig syn på hva en selvmordsfors $\varnothing$ ker trenger?

Den planlagte ansvarsgruppen med faste nøkkelpersoner som skulle opprettes på Fylkessjukehuset i Molde kom aldri i gang, og det fantes heller ingen sosionom der som kunne følge opp selvmordsfors $\varnothing$ kere. Vi manglet derfor viktige brikker internt i sykehuset for å få til et samarbeid. Fagfolk i psykiatrien har kanskje ikke samme tradisjon som familieterapi 
tradisjonen i å tenke "familie/par-problematikk" når de møter selvmordsfors $\varnothing$ kere. Og kanskje er mange innen psykiatrien for individorienterte i sin tilnærming, slik tradisjonell behandling av selvmordsfors $\varnothing$ kere har vært, der fokus i hovedsak er på helse og det som befinner seg inne i personen. Det ser dessuten ut som det for det psykiatriske fagfeltet er mer praktisk å henvise til instanser som er under samme hatt både fysisk og administrativt, som psykiatrisk poliklinikk og psykiatrisk ungdomsteam.

Familievernkontoret er geografisk plassert et annet sted, og kommer dermed lenger ute i en behandlingskjede rent fysisk.

Kan det være slik at i et område med et godt utbygd psykiatritilbud vil et familievernkontor ikke ha en naturlig plass i det selvmordsforebyggende arbeidet? Erfaringer fra andre familievernkontor viser at de kontorene som har jobbet med selvmordsfors $\varnothing \mathrm{k}$ og annen suicidalproblematikk, enten har befunnet seg i områder med spinkelt psykiatritilbud eller med et somatisk sykehus med "aktive" rutiner i forhold til selvmordsfors $\varnothing$ kere.

Jeg har arbeidet med to prosjekter der andre etater har invitert til samarbeid med det psykiatriske fagfeltet, først somatiske avdelinger fors $\varnothing \mathrm{kt}$ koblet opp til psykiatrisk avdeling, og i neste omgang familievernkontor fors $\varnothing \mathrm{kt}$ koblet opp til psykiatrisk avdeling. Mitt inntrykk er at psykiatrien viser til dels liten interesse og dermed kan komme til å svikte som samarbeidspartner. Er det slik det blir når man har monopol?

Om hvem det er som tradisjonelt har hatt enerett til å drive behandling i "det snevre og lukkede behandlingsrommet" sier Hammerlin og Schjelderup: "Den selumordsforebyggende virksomheten har hittil $i$ hovedsak vært styrt av helseprofesjoner, og $i$ svært liten grad blitt gjort til gjenstand for innflytelse fra andre grupper eller enkeltmennesker. For a spissformulere dette vil vi si at en fortsatt ensidig profesjonskon-troll over virksomheten med diagnosti-sering og behandling av depresjoner som det viktigste virkemidlet, kan føre til at man opprettholder og forsterker faglig hegemoni. Vesentlige sider ved både årsaks- og tiltaksforståelsen som er knyttet til selumordsproblemet forblir med dette uløst."

\section{Hva laerte vi?}

Familievernkontoret har gjennom prosjektet skaffet seg st $\varnothing$ rre kompetanse på forholdet mellom selvmordsproblematikk og relasjoner i parforhold og familien. Særlig har vi fătt større innsikt i menns problemer. Derfor er det en utfordring for familievernet å profilere seg slik at menn opplever at de kan komme til oss før de er helt på kanten av livet.

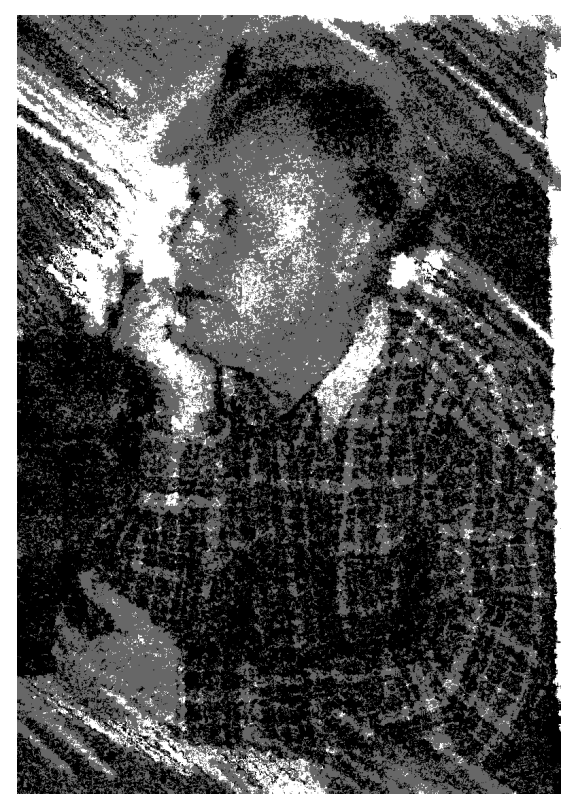

\section{Hva skjer videre?}

På vårt kontor $\varnothing$ nsker vi fortsatt å registrere selvmordsadferd/tanker hos våre klienter. Videre $\varnothing$ nsker vi å holde levende den problemstillingen prosjektet reiste: Hvilken plass har familievernet $i$ det selvmordsforebyggende arbeidet? Vi vet at vi har fått "vist fram" familievernet i løpet av prosjektperioden. Vi blir fortsatt spurt om å undervise og holde kurs for helse- og sosialfaglig personell. Vårt samarbeid med skolen og helses $\varnothing$ stre har f $\varnothing \mathrm{rt}$ til at flere ungdommer s $\varnothing$ ker til eller blir henvist til familievernet. Flere etterlatte etter selvmord kommer til oss nå enn tilfellet var i prosjektperioden. Kanskje betyr dette at når vi skal måle effekten av et prosjekt, må vi også ta i betraktning hva som skjer i tiden etterpå. Hva slags konsekvenser erfaringene vi har gjort får for arbeidet vårt og hvilke sekundæreffekter og etterdønninger prosjektet fører med seg, overskuer vi vel ikke ennå, men noe har skjedd både hos oss selv og hos dem vi ønsker å hjelpe.

\section{Litteratur:}

Aftenposten nov 1995:

Intervju med professor Tore Bierke:

"Nedgang i selvmordsfors $\phi \mathrm{k}$ blant kvinner"

Bærumsmodellen 1984-1994. - Oslo: Statens helsetilsyn, [1996] - 48s. (Skriftserie / Statens helsetilsyn : 1-96, IK-2524) “... utarbeidet av en arbeidsgruppe med ... Wenche Hauk $\varnothing$ som leder"

Foss, Kirsti. Familievern: selvmordsforebygging. Molde : Familievernkontoret i Molde, 1998.

Foss, Kirsti. Moldemodellen: organisering av mottak, behandling og tiltakskjede i sykehus etter selvmorsfors $\phi k$.

Molde: Fylkessjukehuset i Molde, 1996.

Hammerlin, Yngve / Schjelderup, Georg. Når livet blir en byrde: selvmordsforståelse og problemer ved forebygging. Oslo: Ad Notam Gyldendal, 1994.

Brosjyre: Når et selvmordsfors $\phi k$ skjer og det er problemer i familien. Trenger du hjelp til å snakke om det? Utg av Familievernkontoret i Molde

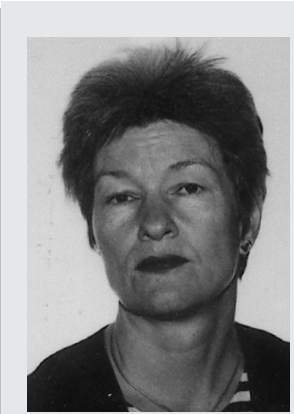

Kirsti Foss er sosionom med klinisk videreutd. i psykiatrisk sosialt arbeid og familieterapi. Hun har arbeidet i flere år med rehabilitering i voksenpsykiatrien og arbeider nå ved Familievernkontoret i Molde. I perioden 1994/ 95 var hun prosjektleder for Moldemodellen v/Fylkessjukehuset i Molde, og i 1996/97 for prosjektet

Familievern og selvmordsforebygging i Molde.

\section{Sitat:}

"Den enkelte har aldrig med et andet menneske at gøre uden at han holder noget af dets liv i sin hånd. Det kan vaere meget lidt, en forbigående stemning, en oplagthed, man fär til at visne, eller som man voekker, en lede man uddyber eller haever. Men det kan også vaere forfaerdende meget, så det simpelthen står til den enkelte, om den andens liv lykkes eller ej."

K. E. Løgstrup: Fra "Analyse av tilliten" i "Den etiske fordring".

København: Gyldendal, 1989 